\title{
COCONUT MITE, (Aceria guerreronis, Keifer) - Bibliography
}

\author{
Ponniah Rethinam and Muhartoyo*)
}

\section{Introduction}

Coconut mite, Aceria guerreronis, Keifer, which made its first appearance as pest in Mexico in 1965 as reported by Keifer, has spread far and wide. Now that 37 years have passed. Research efforts have been made on various aspects of this pest like, origin, occurrence, dispersal, symptoms, population dynamics, management practices like chemical control, bio control, cultural practices, varietal resistance/ tolerances, natural enemies, phytosanitary efforts etc. Two international seminars/ workshops have been held. Many group discussions, steering committee meetings, etc. were also held. Lots of publications have come. An earnest attempt has been made to collect the available literature on this pest which can benefit the member countries and others to know what has been done and what directions one has to move for future research and development. However, this bibliography is not the completed one. There may be many more and we will update as and when we get access to those references. We are confident that this bibliography will help to avoid duplication and take up need based research and development on Eriophyid mite.

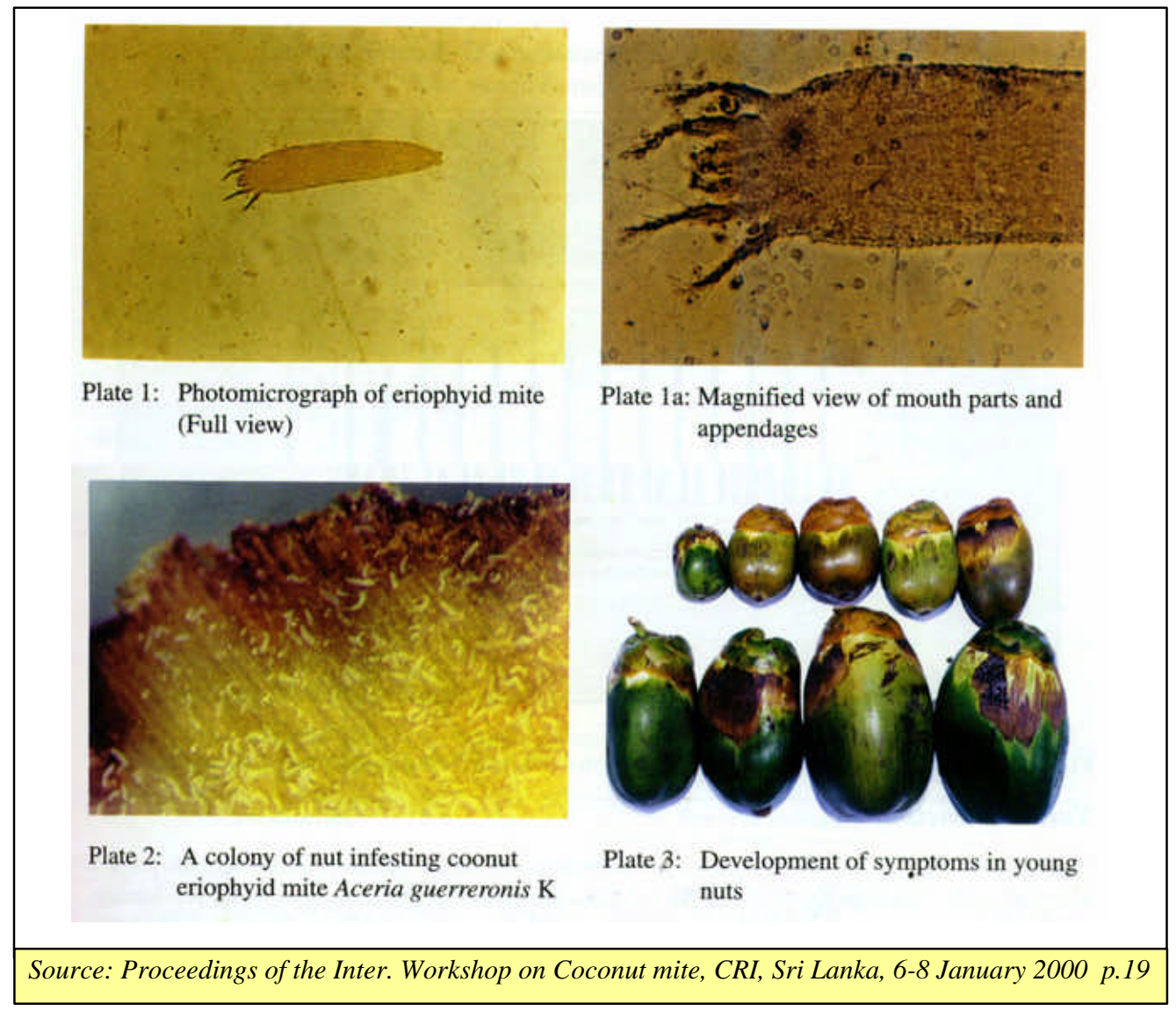

${ }^{*)}$ APCC Secretariat, Jakarta, Indonesia. 


\section{Bibliography}

Amrine, Jr. J.W. and Stasny, T.S. (1994). Catalog of the Eriophyoidea (Acarina : Prostigmata) of the world. Indira Publishing House, Michigan, USA, 804 pp.

Anderson, E.A. (1969). Plants, Man \& Life. University of California Press, Berkeley, $251 \mathrm{p}$.

Anon., (1989). Eriophyes guerreronis. Olegineux, 44: 130 - 131.

Anonymous. (1986). Bayer report. 7pp.

Aquino, M.L.N. de, Flechtmann, C.H.W. and Arruda, G.P. (1968). Contribuicaó ao estudo do acaró causador da necrose do olho do coqueiro em Pernambuco a seu controle. Boletim Tecnico 34, Secretaria de Agricultura, IPA, Recife, 15pp.

Arulmozhi, K. (2000). Containing the eriophyid mite in coconut. In Proceedings International Workshop on Coconut Mite, CRI. Sri Lanka, pp.50-53

Bateman, R. (1998) Delivery systems and protocols for biopesticides. lit: F.R. Hall and J.J. Menn (eds.). Methods in Biotechnology, Vol 5: Biopesticides: Use and Delivery, Totowa N.J: Humana Press, pp.509-528.

Bateman, R., Carey, M., Moore, D. and Prior, C. (1993). Oil formulations of entomopathogenic fungi infect desert locust at low humidities. Annals of Applied Biology 122: 145-152.

Becerra Leor, E. N. (1983). Plagas y enfermedades del cocotero (Cocos nucifera L.). EN: Simposio Nacional de Parasitologia Agricola. Memorias. Jalapa, Veracruz. IAP: pp. 27-30.

Bellotti, A.C., Smith, L. and Lapointe, S.L. (1999). Recent advances in cassava pest management. Annual Review of Entomology 44: 343-370.

Blanford, S. and Thomas, M.B. (1999). Host thermal biology: the key to understanding host-pathogen interactions and microbial pest control? Agricultural and Forest Entomology 1 : 195-202.

Boucias, D.G., Farmerie, W.G. and Pendland, J.C. (1998). Cloning and sequencing of cDNA of the insecticidal toxin hirsutellin A. J. Invertebr. Pathol. 72: 258-261.

Boucias, D.G., McCoy, C.W. and Joslyn D.J. (1982). Isozyme differentiation among 17 geographical isolates of Hirsutella thompsonii. J. Invertebr. Pathol. 39: 329-337.

Brady, B. L. (1981). Fungi as parasites of insects and mites. Biocontrol News and Information 2 (4): 281-296.

CAB International (1999). CABPESTCD 1973-1988 and 1989 August 1999. CAB International, Wallingford.

Cabrera R. I. y Carmen Dfaz, M. del (1995). Eficacia de un programa de saneamiento y control quimico para reducir la reinfestacion y los danos del acaro del cocotero Eriophyes gurerreronis. Datos sin publicar.

Cabrera, R. 1. (1980). Estudio de la distribucion geografica del hongo Hirsutella thompsonii en [as diferentes zonas citricolas del pas. Cienc. y tecn. en la Agricultura. Cftricos y otros Frutales. 3(3): 19-32.

Cabrera, R. 1. (1995). Un medio a base de soya mas azucar para la produccion de Hirsutella thompsonii var. thompsonii en medio liquido. III Encuentro Nac. Cient-Tec. de Bioplaguicidas. Expo-CREE, La Haban, Cuba. pp 1 1-12.

Cabrera, R. I. (1977). Estudio en Cuba de Hirsutella thompsonii Fisher. Control biologico del acaro del moho Phylloeoptruta oleivora Ashm. Agrotecnia de Cuba 9 (11): pp.3-1 1 . 
Cabrera, R. I. (1982). El hongo Hirsutella thompsonii y su importancia en el control del acaro del cocotero. Eriophyes guerreronis en Cuba. $1^{\text {era }}$ Jornada Cient. Inst. de Zool., A.C.C. La Habana, Resumen. pp. 46.

Cabrera, R. I. (1991). El ácaro Eriophyes guerreronis, su importancia economica y métodos de lucha. Resena. Boletin especial. CIDA: pp.40.

Cabrera, R. I. (1992). Un medio simplificado para la produccion a gran escala del hongo Hirsutella thompsonii en cultivo sumergido. Resumenes I Curso Internacional sobre produccion de Hirsutella para el control biologico de acaros. Guantanamo, Cuba.

Cabrera, R. I. y Dominguez, D. (1988). Hirsutella tydeicola, un nuevo entomopatogeno de Tydeus californicus para Cuba. En Primer Simposio de Zoología y Segundo Simposio de Botanica. Palacio de Convenciones. Ciudad de la Habana, Cuba. Libro de Resumenes. pp.127.

Cabrera, R. I. y Nora Sanchez. (1992). Metodologia para la aplicacion del hongo Hirsutella thompsonii en areas de citricos que requieran de su colonizacion y/o reposicion. I Curso Internacional sobre produccion de Hirsutella para el control biologico de acaros. Guantanamo, Cuba.: 4 pp.8-52.

Cabrera, R. I. y Sanpedro, L. (1992). Produccion del hongo Hirsutella thompsonii. I Curso Internacional sobre produccion de Hirsutella para el control biologico de acaros. Guantanamo, Cuba. pp. 29-42.

Cabrera, R. I., Dominguez, D. y Nora Sanchez. (1991). Metodologia para la produccion del hongo Hirsutella thompsonii en cultivo mixto. ENSAC, IICF, La Habana, pp.7.

Cabrera, R. I., G. Otero Colina y Rodriguez, N. (1992). Principales enemigos naturales del acaro del cocotero A. guerreronis (Eriophydae) en Cuba. Agrociencia. Proteccion vegetal 3(2): pp.83-89.

Cabrera, R.1. Dominguez, D. (1987a). El hongo Hirsutella nodulosa, nuevo parasito para el acaro del cocotero Eriophyes guerreronis. Ciencia y Tecnica en la Agricultura. Citricos y Otros Frutales. Vol. 10 (1): pp.41-51.

Cabrera, R. I., y Dominguez, D. (1987b). Hirsutella nodulosa a Hirsutella kirchneri dos nuevos hongos patogenos del acaro del moho P. oleivora. Cienc. y tecn. en la Agricultura. Citricos y otros Frutales 10(2): pp.139-142.

Cabrera, R. L, Nora Sanchez y Domiguez, D. (1992). Resultados en Cuba sobre la produccion del hongo Hirsutella thompsonii en cultivo mixto. I Curso Internacional sobre produccion de Hirsutella para el control biologico de acaros. Guantanamo, Cuba.

Cabrera, R.I. Cabrera (2000). Biological control of the coconut mite, Aceria guerrenis (Acari: Eriophyidae) with the fungus Hirsutella thompsonii and its integration with other control methods. In Proceedings International Workshop on Coconut Mite, CRI. Sri Lanka, pp. 89-103

Cabrera, R.I., Caceres, I. and Dominguez, D. (1987). Estudio de dos especies del bongo de Hirsutella y sus hospedantes en el cultivo de la guayaba Psidium guajava. Agrotecnia Cuba 19: pp.29-34.

Cabrera, R.I., Otero Colina, G. and Rodriguez, N. (1992). Principales enemigos naturales del acaro del

Cabrera, R.I. (2000). Biological control of the coconut mite, Aceria guerreronis (Acari: Eriophyoidea) with the fungus Hirsutella thompsonii and its integration with other 
control methods. Paper presented at "International Workshop on coconut eriophyid mite" held at CRI, Sri Lanka, Jan. 5-7, 2000. 15 pp.

Cabrera. R. I. N. Rivero y Gonzalez, R. (1981). Primeros eetudios comparativos del control biologico y quimico del acaro del moho (Phyllocoptruta oleivora) Memorias ler. Cong. Nac. de Citricos y otros Frutales. Tomo II: pp.63-89.

Carbrera, R.I. and Dominguez, D. (1987). El hongo Hirsutella nodulosa, nucvo parasito para el acaro del cocotero Eriophyes guerreronis. Ciencia y Tecnica en la Agricultura, citricos y otros Frutales, 10: pp.4 I -51.

Calvez, C.H., (1999). Report on the visits to Madal Plantations : 24 November -3 December 1998, CIRAD, Montpellier, France.

Chararas, C. (1979). Ecophysiologie des insectes parasites des forests. The Author; Paris, France.

Chezhian, N. and Ramar, A. (2000). Eriophyid mite incidence on different varieties of coconut. Paper presented in group meeting on coconut eriophyid mite, Aceria guerreronis K. on 15th May, 2000 at Tamil Nadu Agricultural University, Coimbatore-3.

David, B.V. and Kumaraswamy, T. (1978). Elements of Economic Entomology. Population Book Depot., Madras, India. 514 pp.

De Jong, D.; Morse, R.A. and Eickwort, G.C. (1982). Mite pests of honey bees. Аnnu. Rev. Entomol. 27: 229-252.

De Moraes, G.J. (2000). Use of predatory mites for the control of eriophyid mites. In Proceedings International Workshop on Coconut Mite, CRI. Sri Lanka, pp.78-88

Doraisamy, Sabitha, K. Ramaraju, P. Karuppuchamy and S. Palaniswamy (2002). Present status of eriophyid mite damage on coconut and its management. In Intensified Coconut Production with Floriculture Edited by H.P. Singh and Sugata Ghose., Coconut Developmen Board, India. pp46-54.

Doreste, E. (1968). El acaro de la flor del cocotero (Aceria guerreronis, Keifer) en Venezuela. Agionoinia Tropical 18 (3): 379-386).

Espinosa Becerril, A.; Carrillo Sanchez, J.L. (1986). The fungus Histutella thompsonii Fisher of the control of eriophyid Eriophyes gerreronis (Keifer). Agricultura Tecnica en Mexico v. 12 (2) p319-323.

Estebanes Gonzalez, M.L. (1976). Acaros depredadores deEriophyes guerrernnis (Keifer) en la zona de Tecpan de Galeana, Gro. Folia Entomol. Mexicana 39/40: 41-42.

Estrada, J. Y Gonzalez, M. (1975). Danos causados en coco por Aceria guerreronis-(Acarina: Eriophydae) en Cuba. Rcvista de la Agricultura 8 (2): 30-34.

Fernando, L.C.P.; Wickramananda, I.R. and Aratchige, N.S. (2000). Status of Coconut Mite, Aceria guerreronis in Sri Lanka. In Proceedings International Workshop on Coconut Mite, CRI. Sri Lanka, pp1-8

Fisher, F.E. (1950). Two new species of Hirsutella Patouillard. Mycologia 42 (2): 290-297.

Flechtmann, C.H. W (1989). Cocos weddelliana H. Wendl. (Palmae: Arecaceae), a new host plant for Eriophyes guerreronis (Keifer, 1965) (Acari: Eriophyidae) in Brazil. International Journal of Acarology 15: 241.

Frankenhuyzen, K. van (1993). Bacillus thuringiensis. An environmental biopesticide: Theory and Practice, PF. Entwistle, J.S. Cory, M.J. Bailey and S. Higgs (Eds). John Wiley and Sons Ltd. pp. I-35. 
Garcia, R. V. de M., Carmona. M. (1968) Aceria guerreronis Keifer (Acarina: Eriophydae). Uma especie nova para S.Tome a Pricipe. Acta Bioltigica 10(3): 353-358.

Geethhalakshmi, L. and Rabindra, R.J. (2000). Effect of eriophyid mite infestation on button shedding and quality parameters in coconut. Paper presented in group meeting on coconut eriophyid mite, Aceria guerreronis K. on $15^{\text {th }}$ May, 2000 at Tamil Nadu Agricultural University, Coimbatore-3.

Gerson, U., Kenneth, R. and Muttah, T. I. (1979). Hirsuttella thompsonii, a fungal pathogenic of mites. 11. Host-pathogen interactions. Ann. Appl. Biol. 91: 2940.

Gillespie, A.T., (1988). Use of fungi to control pests of agricultural importance.In: M.N. Burge (Editor), Fungi in biological control systems. Manchester Univ. Press, Manchester, UK, pp.37-60.

Griffith, R. (1984). The problem of the coconut mite, Eriophyes guerreronis (Keifer), in the coconut groves of Trinidad and Tobago. In: R, Webb, W. Knausenberger and L. Yntema (Eds.). Proc. 20th Ann. Meeting of the Caribbean Food Crops Soc. East Caribbean Center, College of the Virgin Islands and Caribbean Food Crops Soc., St. Croeix, Virgin Islands, USA. pp.128-132

Gunathilagaraj, K. (1984). Annual Report. Plant clinic centre, Tamil Nadu Agricultural University, Srivilliputhur, Tamil Nadu, India.

Gupta, YN. and Gupta, S.K. (1978). On a collection of tetranychoid mites from Madhya Pradesh, India, with a description of a new Eotetranychus(Acari: Trombidiformes). Indian J. Acarol. 3: 87-91.

Gutierrez, J. and Schicha, E. (1984). Phytoseiidae and Tetranychoidea in Fiji and other South Pacific Islands (Acari). Int. J. Entomol. 26(4): 386-388.

Hagen, K.S. (1976). Role of nutrition in insect management. Proceedings of the Tall Timbers Conference on Ecological Animal Control by Habitat Management. Tall Timbers Research Station, Tallahassee, Florida. 6: 221-261.

Hall, R.A; Hussey, N.W., Mariau, D. (1980). Results of a survey of biological control agents of the coconut mite, Eriophyes guerreronis. Oleageneux 35: 395-400.

Hall, R.A. and Espinosa B., A., (1981). The coconut mite, Eriophyes guerreronis, with special reference to the problem in Mexico. Proc. 1981 British Crop Protection Conf. - Pests and Diseases, British Crop Protection Council. Farnham, UK, pp. 113-120.

Haq, M.A. (1999a). Coconut mite threat in Kerala. J. Acarol. 14 (1 \& 2): 58-63.

Haq, M.A. (1999b). Amazing trend in distribution of Aceria guerreronis in peninsular India and adjacent Islands. Entomon (Accepted).

Haq, M.A. (2000). Outbreak of coconut mite in Kerala. Experimental and Applied Acardology (In Press)

Haq, M.A. K. Sumangala and N. Ramani (2000). Coconut mite invasion, injury and distribution. In Proceedings International Workshop on Coconut Mite, CRI. Sri Lanka, pp 41-49

Henderson, C.F and McBurnie, H.V. (1943). Sampling techniques for determining populations of the citrus red mite and its predators. U.S.D.A. Circular No.671, 11 pp.

Hernandez Roque, F. (1977). Combate quimico del eriofido del cocotero Aceria (Eriophyes) guerreronis (K). Agricultura Tecnica. Mexico 4 (1): 23-38. 
Hessein, N.A. and Perring, TM. (1986). Feeding habits of the Tydeidae with evidence of Honieoproneincitits anconai (Acari: Tydeidae) predation on Aculops lycopersici (Acari: Eriophyidae). hit. J. Acarol. 12 (4): 215-221.

Howard, F.W, Abreu-Rodriguez, E. and Denmark, H.A. (1990). Geographical and seasonal distribution of the coconut mite, Aceria guerreronis (Acari: Eriophyidae), in Puerto Rico and Florida, USA. Journal of Agriculture of University Ptterto Rico 74 (3): $237-251$.

Howard, F.W. and Abreu-Rodriguez, E.A. (1991). Tightness of the perianth of coconuts in relation to infestation by coconut mites. Florida Entomologist 74: 358-361.

Jeppson, L.R., Keifer, H.H. and Baker, E.W. (1975). Mites injurious to economic plants. Univ. Calif. Press, Berkeley, CA.

Julia, J.F. and Mariau, D., (1979). Nouvelles researches en Cote-d'Ivoire sur Eriophyes guerreronis K., acarien ravageur des noix du cocotier. Oleagineux, 34: 181-189.

Julia, J.F., Mariau, D., Hall, R. (1979). Nouvelles recherches en Cote d'Ivoire sur Eriophyes guerreronis K., acarien ravageur des noix du cocotier. Congress sur la lutte contre les insectes en milieu tropical. Chambre de Commerce et d'Industrie de Marseille, 13-16 Mars. 1979. Compte rendu des travauz. Premiere partie. Cultures topicales. Deuxieme partie. Sante humaine et animale. 373-387.

Kamala Thirumalaiswamy, S. Senthil, J. Rajkumar, M. Thangaraj and P S. Srinivasan. (2000). Root feeding of nutrients and growth regulators for inducing resistance and rejuvenation of coconut palms infested by eriophyid mite. Paper presented in group meeting on coconut eriophyid mite, Aceria guerreronis $K$. on $15^{\text {th }}$ May, 2000 at Tamil Nadu Agricultural University, Coimbatore-3.

Kannaiyan, S.; Kumar, K.; Gopalsamy, G.; P Yasotha and K. Ramaraju. (2000a). Evaluation of a formulation based on plant products, biocides and agrochemicals for its efficacy against eriophyid mite in coconut. Paper presented in Interactive workshop on coconut eriophyid mite held on $19^{\text {th }}$ May, 2000 at Tamil Nadu Agricultural University, Coimbatore-3.

Kannaiyan, S., Rabindra, R.J.; Ramaraju, K.; Sabitha Doraiswamy (2002). Integrated Management of eriophyid mite on coconut. Tamil Nadu University, Coimbatore, India.

Kannaiyan, S.; Sabitha Doraisamy, R.J.; Rabindra, G. Ramakrishnan and R. Bhaskaran. (2000b). Integrated packages for the management and control of coconut eriophyid mite. Paper presented in the 66th Scientific Workers conference held on $19^{\text {th }}$ and $20^{\text {th }}$ July, 2000 at Tamil Nadu Agricultural University, Coimbatore. 99-109.

Karuppuchamy, P.; Rabindra, R.J. and R. Philip Sridhar. (2001). Evaluation of spot application of insecticides for the management of coconut eriophyid mite Aceria guerreronis Keifer. In: IPM in Horticultural Crops: Emerging trends in the new millenium (Eds: Abraham Verghese and P.Parvatha Reddy), IIHR, Bangalore. $11-112$.

Keifer, H.H. (1965). Eriophyid studies B-14, California, Department of Agric., Bureau of Entomol. 20 pp.

Kennedy, G.G. and Smitley, D.R. 1988. Method of controlling plant feeding mites with the fungus Neozygites floridana. US Patent 4,752,468, $7 \mathrm{pp}$.

Kenneth, R., Muttath, T. L. and Gerson, U. (1979). Hirsutella thompsonii, a fungal pathogen of mites. I Biology of the fungus in vitro. Ann. Appl. Biol. 91: 21 - 28. 
Knop, N.F. and Hoy, M.A. (1983) Biology of a tydeid mite, Homeoproneinatus anconai (n. comb.) (Acari: Tydeidae), important in San Joaquin Valley Vineyards. Hilgatdici 51(5): 1-27.

Krantz, G.W. (1975). A Manual of Acarology. Second Edition. Oregon State University Book Stores, Inc., Corvallis, 509 p.

Kumar, K.; Gopalasamy, G.; Yasotha, P. and S. Kannaiyan. (2000). Selection of antagonistic microflora effective against coconut eriophyid mite. Paper presented in Interactive Workshop on coconut eriophyid mite held on $19^{\text {th }}$ May, 2000 at Tamil Nadu Agricultural University, Coimbatore-3.

Kuttalam, S.; Manoharan, T.; Chandrasekaran, S.; Jayakumar, R.; Chinniah, C.; Vijayalakshmi, K.; Santharam, G. and R.J. Rabindra. (2000). Residues of insecticides used for eriophyid mite management in coconut. Paper presented in group meeting on coconut eriophyid mite, Aceria guerreronis K. on $15^{\text {th }}$ May, 2000 at Tamil Nadu Agricultural University, Coimbatore-3.

Kuttalam, S.; Manoharan, T.; Chandrasekaran, S., Jayakumar, R.; Ramaraju, K. Chinniah, C. and K. Vijayalakshmi. (2001). Profenofos Insecticide residues in coconut after root feeding. Paper presented in National seminar on Emerging Trends in Pests and Diseases and their Management on 11-13 ${ }^{\text {th }}$ October, 2001 at Tamil Nadu Agricultural University, Coimbatore-3.

Laing, J.E. and Knop, N.F. (1983). Potential uses of predaceous mites other than Phytoseiidae for biological control of orchard pests. In: M.A. Hoy, G.L. Cunningham \& L. Knutson. 1983. Biological Control of Pests by Mites. Proc. Conf. held April 5-7, 1982 at Univ. California, Berkeley. Agric. Exp. St., Div. Agric. Natural Res., Univ. California, Spec. Public. 3304: 28-35.

Lampedro, L. and Rosas, J.L. (1989). Selection of Hirsutella thompsonii Fisher strains to fight the coconut mite Eriophyes guerreronis Keifer. I. Pathogenecity bioexperiments. Revista Mexicanna de Micologia 5: 225-231.

Latge, J. P., Cabrera, R. I. and Prevost, M. C. (1988). Microcycle conidiation in Hirsuttella thompsonii. Can. J Microbiol. 34: 625 - 630.

Lindquist, E.E. (1986). The world genera of Tarsonemidae (Acari: Heterostigmata): a morphological, phylogenetic, and systematic revision, with a reclassification of family-group taxa in the Heterostigmata. Mem. Entomol. Soc. Canada, 136: 1-517.

Mains, E. B. (1951). Entomogenous specie of Hirsutella, Tilachlidium and Synnematium. Micologa. 43(6): 691 - 718.

Manian, R., K. Kathirvel and T. Senthil Kumar. (2000). Development of spraying devices for spot application of pesticides on coconut bunches. Paper presented in group meeting on coconut eriophyid mite, Aceria guerreronis K. on $15^{\text {th }}$ May, 2000 at Tamil Nadu Agricultural University, Coimbatore-3.

Manickam, A., Kokiladevi, E. and Thayumanavan, B. (2001). Biochemical basis of eriophyid mite infestation in coconut. Paper presented in National seminar on Emerging Trends in Pests and Diseases and their Management on 11-13 ${ }^{\text {th }}$ October, 2001 at Tamil Nadu Agricultural University, Coimbatore-3. 88-89.

Mariau, D. (1969). Aceria guerreronis (Keifer) Recente ravageur de 1a cocoteraies africaines et americaines. Oleagineux 24(5): 269-272.

Mariau, D. (1977). Aceria (Eriophves) guerreronis: un important ravageur des cocoteraies africaines et americaines. Oleagineux 32(3): 101-111. 
Mariau, D. (1986). Comportement de (Eriophyes) guerreronis Keifer a leyard de differentes varietes de cocotiers. Oleagineux 41: 499-505.

Mariau, D. (1993). Insecticides recommended against oil palm and coconut pests. Oleagineux 48 (12): 530-532.

Mariau, D. and Julia, J.R. (1970). L'acariosea Aceria guerreronis (Keifer), ravageur du cocotier. Oleagineux, 25:459-464.

Mariau, D. y Tchibozo, H. M. (1973). Essais de lutte chimique contre Aceria guerreronis-Keifer. Oleagineux 28 (3): 133-135.

Markose, VT. (1999). An overview of the coconut industry in India. Paper presented at the World Coconut Day Seminar at Kochi, India, Sept.2, 10p.

Martyn, E. B. (1949). Notes on a visit to Columbia. Trop. Agric. (Trinidad), 26: 48-50

McCoy, C. W (1978). Entomopathogens in arthropod pest control programs for citrus. In: Future Strategies in Pest Management Systems. (G. E.Allen, C. N. Ignoffo and R. Plaques) pp.211-224.

McCoy, C.W (1980). Pest control by the fungus Hirsutella thompsonii. In: Microbial control pest and diseases. Burges (De.). Academic Press. pp.499-512.

McCoy, C.W (1996). Pathogens of eriophyoids. In: Eriophyoid Mites - Their Biology, Natural Enemies and Control, E.E. Lindquist, M.W. Sabelis and J. Bruin (eds), pp. 481-490. Elsevier Science B.V ,Amsterdam.

McCoy, C.W and Selhime, A.G. (1977). The fungus pathogen, Hirsutella thompsonii and its potential use for control of the citrus mite in Florida. In: Proc. Int. Citrus Congr., (2), 521-527. Murcia, Spain.

McCoy, C.W Couch,T L., and Abbott Laboratories. (1982). Microbial control of the citrus rust mite with the myeoaearicide MYCA®. The Florida Entomologist 65(1): 1 16-126.

McCoy, C.W, Shelime, A.G., Kanavel, R. F and Hill, J. (1971). Suppression of citrus rust mite populations with application of fragmented mycelio of Hirsutella thompsonii. J. Invert. Pathol. 17(2): 240-276.

McCoy, C.W. and Couch, T. L. (1978). Hirsutella thompsonii: A potential micoacaricide. Developments in Industrial Microbiology. 20:89-96.

McCoy, C.W. and Heimpel, A.M. (1980). Safety of the potential mycoacaricide, Hirsutella thompsonii, to vertebrates. Environm. Entom. 9: 47-49.

McCoy, C.W. and Kanavel, R.F. (1969). Isolation of Hirsutella thompsonii from the citrus rust mite, Phyllocoptruta oleivora, and its cultivation on various synthetic media. J. Invertebr. Pathol. 14: 386-390.

McCoy, C.W., Hill, A. J, and Kanavel, R. F. (1972). A liquid medium for the large scale production of Hirsute lla thompsonii in submerge culture. J. Invert. Pathol. 19(3): 370-374.

McCoy, C.W., Hill, A. J, and.Kanavel, R. F. (1975). Large scale production of the fungal pathogen Hirsutella thompsonii and its formulation for application in the field. Entomophaga 20(3): 229-240.

McCoy, C.W., Hill, A.J. and Kanavel, R.F. (1975). A liquid medium for the large-scale production of Hirsutella thompsonii in submerged culture. J. Invertebr. Pathol. 19: 370-374. 
McCoy, C.W., Stamper, D.H and.Tuveson, R. W. (1984). Conidiogenous cell differences among mutant and wild-type pathotypes of Hirsutella thompsonii. var. thompsonii . J. Invert. Pathol. 43: 414-421.

McEnroe, W.D. (1961). Guanine excretion by the two-spotted spider mite (Tetranychus telarius (L.)). Ann. Entomol. Soc. Am. 54: 926-926.

McMurtry, J.A. (1991). Augmentative releases to control mites in agriculture. In: Dusbabek, F. \& V. Bukva (Eds.). Modern Acarology, Academia, Praga \& SPB Academic Publishing bv, The Hague, v. 1, pp. 151-157.

McMurtry, J.A. (1992). Dynamics and potential impact of generalist phytoseiids in agroecosystems and possibilities for establishment of exotic species. Erp. $8 \mathrm{c} \mathrm{Appl.}$ Acciiol. 14: 371-382.

McMurtry, J.A. and Croft, B.A. (1997). Life-styles of phytoseiid mites and their roles in biological control. Ann. Rev. Entomol. 42: 291-321.

McMurtry, J.A. and Scriven, G.T (1964) Biology of the predaceous mite Typhlodroinus rickeri (Acarina: Phytoseiidae). Ann. Entomol. Soc. Anier. 57: 362-367.

Meena, C. J. (1996). Consultants report on the evaluation of the damage caused by the coconut mite Eriophyes (Aceria) guerreronis Keifer (Acari: Eriophyidae) to coconut in Tanzania, pp. 27 (unpublished).

Meir, T. et at. (1989). Study on innocuity of hirsutella thompsonii. Ineffectivity in mice and guinea pig. Entomophaga (France) v.34 (1): 105-110.

Mezei, I. (1995). Adatok a Quadrastichus (Mvioinisa)sajoi (Szelenyi) (Hymenoptera, Chalcidoidea) biologiajahoz. Novenyvedelem (Hungary), 31(5): 211-214.

Mier, T, Perez, J.; Carrillo-Farga, J. y Toriello, C. (1989). Study on the innocuity of Hirsutella thompsonii. Infectivity in mice and Guinea pigs. Entomophaga 34 (1): 105-110.

Minter, D.W. and Brady, B.L. (1980). Mononematas species oh Hirsutella. Trans. Br. Micol. Soc. 74(2): 271-282.

Mohanasundaran, M.; Kalyanasundaram, S.; Somasundaram, Ova and Mahendran, R. (1999). Management and control measures for the coconut eriophyid mite, Aceria guerreronis Keifer (Eriophyidae : Acari) in Tamil Nadu. Indian Coconut Journal 29 (9): 8-10.

Moore, D and Alexander, L and Hall R.A (1990). Resistance of coconut in St Lucia to attack by the coconut mite Eriophyes guerreronis Keifer. Tropical Agriculture. (Trinidad) 67 (1): 33-36.

Moore, D. (1986). Bract arrangement in the coconut fruit in relation to attack by the coconut mite Eriophyes guererronis Keifer. Tropical Agriculture. (Trinidad), 63: 285-288.

Moore, D. (2000). Non-chemical control of Aceria guerreronis - Review of research efforts. In Proceedings International Workshop on Coconut Mite, CRI. Sri Lanka, pp.63-70

Moore, D.; Ridout, M.S. and Alexander, L. (1991). Nutrition of coconuts in St.Lucia and relationship with attack by coconut mite Aceria guerreronis Keifer.Trop.Agric .(Trinidad), 68:41-44.

Moore, D. and Alexander, L. (1990). Resistance of coconuts in St. Lucia to attack by the coconut mite, Eriophves guererronis Keifer. Trop. Agric. 67: 33-36. 
Moore, D. and Alexander, L., (1987a). Aspects of migration and colonization of the coconut palm by the coconut mite, Eriophyes guerreronis (Keifer) (Acari: Eriophyidae). Bull. Entomol. Zrres., 77:641-650.

Moore, D. and Alexander, L. (1987b). Stem injection of vamidothion for control of coconut mite, Eriophyes guerreronis Keifer, in St.Lucia. Crop Protection, 6: 329-333.

Moore, D. and Howard, F.W. (1996). Coconuts. In: Eriophyoid mites: Their biology, natural enemies and control. (Eds.) E.E. Lindquist, M.W. Sabellis and J. Bruin, Elsevier Science, Publ. Amsterdam, pp.561-570.

Moore, D. and Howard, F.W. (1996). Coconuts. In: Linquist E.E., Sabelis, M.W., Bruin, J. (eds.), Eriophyoid mites their biology, natural enemies and control. Elsevier. World Crop Pests 6: 41-44.

Moore, D. and Alexander, L. (1987). Stem injection of vamidothion for control of coconut mite, Eriophyes guerreronis Keifer, in St. Lucia. Crop Protection, 6: pp.329-333.

Moore, D. et al. (1988). The coconut mite, Eriophyes guerreronis Keifer in St. Lucia: yield losses and attempts to control it with acaricide, polybutene and Hirstutella fungus. Tropical Pest Management v. 35 (1) pp.83-89

Moore, D., Alexander, L. and Hall, R.A. (1989). The coconut mite, Eriophyes guerreronis Keifer in St. Lucia. Yield losses and attempts to control with acaricide, Polybutene and Hirsutella fungus. Tropical Pest Management 35(1): pp.83-89.

Moore, D; Ridout, M.S.; Alexander, L. (1991). Nutrition of coconuts in St Lucia and relationship of attack by coconut mite Aceria guerreronis Keifer. Tropical Agriculture (Trinidad) 68: pp.41-44.

Moore. D and Alexander, L. (1990) Resistance of coconuts in St. Lucia to attack by the coconut mitc. Eriophyes guerreronis Keifer. Tropical Agriculture. (Trinidad) 67: pp.33-36.

Moraes, G.J. de, McMurtry, J.A. and Denmark, H.A. (1986). A Catalog of the Mite Family Phytoseiidae. References to Taxonomy, Synonymy, Distribution and Habitat. EMBRAPA-Departamento de Difusao de Tecnologia, Brasilia, 353 pp.

Morgan, CXG. and Hedlin, A.F. (1960). Notes of the juniper berry mite, Trisetacus guadrisetus (Thomas) (Acarina: Eriophyidae), in British Columbia. Can. Entoniol. 42: pp.608-610.

Mozez-Koch, R., Edelbaum, O., Edelbaum, O., Livneh, O., Sztejnberg, A., Uziel, A., Gerson, U. and Sela, I. (1995). Identification of Hirstutella species, isolated within a species and heterokaryons by random amplified polymorphic DNA (RAPD). Z. Pflanzenkrankh Pflanzensch. 102: pp.284-290.

Mpunami, A, and Seguni, Z. (1996). Report on a visit to Mozambique to investigate an unknown destructive disease of coconut palm. pp 16 (Unpublished).

Muthiah, C. and Bhaskaran, R. (1999). Screening of coconut genotypes and management of Eriophyid mite Aceria guerreronis (Eriophyidae: Acari) in Tamil Nadu. Indian Coconut Journal 30 (6): pp.10 - 11.

Muthiah, C. and Bhaskaran, R. (2000). Survey, bio-efficacy and management of eriophyid mite on coconut. Paper presented in group meeting on coconut eriophyid mite, Aceria guerreronis K. on $15^{\text {th }}$ May, 2000 at Tamil Nadu Agricultural University, Coimbatore-3. 
Muthiah, C.; Bhaskaran, R. and Kannaiyan, S. (2001). Bio-Ecology and Control of Eriophyid Mite of coconut - An Indian Experience. The Planter, 77 (902): pp.255-263.

Muttath, M.T (1974). Studies on Hirsutella thompsonii Fisher, a fungal pathogen. Master thesis.

Nadarajan, L.; Ranjith, A.M. Thomas, Jim; Pathummal Beevi, S. and Nair, Madhavan (2000). Coconut perianth mite, Aceria (Eriophyes) guerreronis (Keifer) and its management, Kerala Agricultural University, Vellanikkara, pp. 1-10.

Nair, C.P.R. (2000). Status of coconut eriophyd mite, Aceria guerreronis Keifer in India. In Proceedings International Workshop on Coconut Mite, CRI. Sri Lanka, pp. 9-12

Nair, C.P.R. and Koshy, P. K. (2000). Studies on coconut eriophyid mite Aceria guerreronis K. in India. Paper presented at "International Workshop on coconut eriophyid mite" held at CRI, Sri Lanka, Jan. 5-7, 2000. 7 pp.

Nair, G.M.; Mathew, T.B.; Saradamma, K. and Beevi, N. (2000). Infestation of coconut mite (Aceria guerreronis K.) in the Southern Indian State, Kerala. In Proceedings International Workshop on Coconut Mite, CRI. Sri Lanka, pp32-40

Narasimha Rao, B. (2000). Residue of triazophos in coconut water and kernel when administered through roots. Pestology, 24 (1): 2-4.

Nault, L. R. and Styer, W. E. (1969). The dispersal of Aceria tulipae and three other grass-infesting eriophyid mites in Ohio. Ann. Entoinol. Soc. Ant. 62: 1446-1455.

Ocete, R. and Skuhrava, M. (1996). Nota sobre la presencia de Arthroctiocax vitis Rubsaamen (Diptera, Cecidomyiidae) en erineos de poblaciones de vid silvestre de la region Subbetica. Boletin de Sanidad Vegetal - Plagas (Spain), 22(2): 465-468.

Ochoa, R.; Aguilar, H. and Vargas, C. (1991). Acaros Fitofagos de America Central: Guia Ilustrada. Catic, Costa Rica, Serie Tecnica. Manual Tecnico 6, 251 p.

Ochoa, R., Aguilar, H., and Vargas, C. (1994). Phytophagous mites of Central America: An illustrated guide. CATIE, Turrialba, Costa Rica. 234 pp.

Odongo, B.; Odindo, M.O.; Brownbridge, M. and Kumar, R. (1998). Comparative biological efficacy of Hirstutella thompsonii and Neoseiulus teke for cassava mite (Mononychellus tanajoa) suppression. Biosci. Technol. 8:345-355.

Oldfield, G.N. (1996). Diversity and host plant specificity. In: E.E. Lindquist, M.W. Sabelis \& J. Bruin (eds.). World Crop Pests. Eriophyoid Mites. Their Biology, Natural Enemies and Control, Elsevier Sicences, Amsterdam, p. 199-216.

Oldfield, G.N. and Perring, T.M. (1996). Rearing Techniques. Pp. 377-382. In E.E. Lindquist, M.W. Sabelis, and J. Bruin (eds.) Eriophyid mites Their biology, natural enemies and control. Elsevier Science, Amsterdam. 790 pp.

Olvera-Fonseca, S. (1986). El acaro causante de la rona del cocotero en Veracruz, Mexico. (Acarina, Eriophydae). Folia Entoniologica Mexicana 67: 45-51.

Ortega, A., Rodrfguez, J. y Garibal, C. (1965). Investigaciones preliminares sobre el eriofido del fruto del cocotero Aceria guerreronis Keifer en la Costa Grande de Guerrero. Agricultura Tecnica, Mexico 1 (5): 222-226.

Ortega, C.A., Rodriguez,V.J and Garibay,V.C.(1965). Investigaciones preliminares sobre el eriofido del fruto del cocotero Aceria guerreronis Keifer, en la Costa Grande de Guerrero. Agricultura Technica en Mexico, 2: 222-2126. 
Otero Colina, G. (1986). Acaros colectados sobre plantas cultivadas en el Estado de Tabasco, Mexico y su importancia. Folio Entoinol. Mevicana 69: 127-147.

Overmeer, W.P.J. (1985). Techniques. Rearing and handling. In: W. Helle \& M.W. Sabelis (eds.). World Crop Pests. Spider Mites. Their Biology, Natural Enemies and Control, Elsevier, Amsterdam, v. 1 B, pp. 161170.

Palanisamy, S., Karuppuchamy, P.; Ramaraju, K.; Philip Sridhar, R.; Kempraj, T.; Bhaskaran, V. and Rabindra, R.J. (2000). Evaluation of ecofriendly agents and insecticides against coconut eriophyid mite Aceria guerreronis K. Paper presented in group meeting on coconut eriophyid mite, Aceria guerreronis $K$. on $15^{\text {th }}$ May, 2000 at Tamil Nadu Agricultural University, Coimbatore-3.

Pant, N.C.; Srivastava, P.D.; Jotwani, M.G.; Agarwal, R.A.; Wadhi, S.R.; Bhanotar, R.K.; Bhatnagar, R.K. (1982). Insect nutrition and its significance in the management of pests and beneficial insects. Agricultural-entomology 1: 44-53.

Pereira, R. M. and Roberts, D. W (1990). Dry mycelium preparations of entomopathogenic fungi Metarhiziunt anisopliae and Beauveria bassiana. J. Invertehr Pathol. 56: 39-46.

Perring, T. (2000). Eriophyid mite: Special considerations in applied ecological research. In: Proceedings International Workshop on Coconut Mite, CRI. Sri Lanka, 71-77.

Perring, T.M. and McMurtry, J.A. (1996). Other predatory arthropods. In: E.E. Lindquist, M.W. Sabelis \& J. Bruin (eds.). World Crop Pests. Eriophyoid Mites. Their Biology, Natural Enemies and Control, Elsevier Sicences, Amsterdam, p. 471-479.

Perring, T.M., Farrar, C.A. and Oldiield, G.N. (1996). Sampling techniques. Pp. 367-376. In. E.E. Lindquist, M.W. Sabelis, and 1. Bruin (eds.) Eriophyoid mites Their biology, natural enemies and control. Elsevier Science, Amsterdam. 790 pp.

Philip Sridhar, R., K. Ramaraju, P. Karuppuchamy, S. Palanisamy, T. Kempraj, M. Bharathi and R.J. Rabindra. (2000). Evaluation of insecticides against coconut eriophyid mite by root feeding and crown placement. Paper presented in group meeting on coconut eriophyid mite, Aceria guerreronis K. on $15^{\text {th }}$ May, 2000 at Tamil Nadu Agricultural University, Coimbatore-3.

Poinar, G. Jr. and Poinar, R. (1998). Parasites and pathogens of mites. Annu. Rev. Entomol. 43: 449-169.

Ragupathy, A., Palanisamy, S., Chandramohan, N. and Gunathilagaraj, K. (1994). A guide on crop pest. Sooriya Desktop Publishers. Coimbatore, India, 264 pp.

Rai, A.B., Jhala, R.C., Patel, C.B., Patel, V.J., Patel, K.G. and Shah, A.H. (1991). Ecology of Oligonychus indices (Acarina: Tetranychidae) infesting coconut in South Gujarat, India. In: F. Dusbabek and V. Bukva (Eds.). Modern Acarology, Academia, Praga \& SPB Academic Publishing bv, The Hague, v. 1: 559-563.

Ramaraju, K. and R.J.Rabindra. (2001). Palmyra Borassus flabellifer Linn. (Palmae): A host of the coconut eriophyid mite Aceria guerreronis K. Pest management in Horticultural ecosystem. 7 (2) :149-151.

Ramaraju, K., Natarajan, K.; Sundara Babu, P.C. and Murali Ragini, G.T. (1999). Management of coconut edophyid mite, Aceria guerreronis in Tamil Nadu. J. Acarol., 14: 82-83.

Ramaraju, K.; Natarajan, Sundara Babu, K.; Palnisamy, S. and Rabindra, R.J. (2000). Studies on coconut eriophyid mite, Aceria guerreronis Keifer in Tamil Nadu, India. In Proceedings International Workshop on Coconut Mite, CRI. Sri Lanka, p.13-31 
Ramaraju, K., Sundara Babu, P.C., Asaf Ali, K. and Sivasubramanian P. (1998). Acarological Research in Tamil Nadu. Technical Booklet, Department of Agricultural Entomology, Tamil Nadu Agricultural University, Coimbatore, India 30pp.

Ramarethinam, S. and Marimuthu, S. (1998). Role of IPM in the control of eriophyid mite, Aceria (Eriophyes) guerreronis (K.), an emerging menace in the coconut palms in Southern India. Pestology XXII(12): 39-47.

Reed, D.K., Burditt, A.K. and Crittenden, C.R. (1964). Laboratory methods for rearing rust mites (Phyllocoptrctta oleivora and Aculus pelakassi) on citrus. J. Econ. Entontol. 57: 130-133

Rethinam, P., Singh, H.P. and Vyayakumar Hallikeri (2001). Eriophyid mite attack on coconut. State of Art Report. CDB, Kochi. pp.35

Rodriguez, J.G. (1973). Insect and mite nutrition. Significance and implications in ecology and pest management. North-Holland Publishing Company, Amrsterdam. 702pp.

Romney, D.H., (1980). Agronomic performance of "Malayan Dwarf" coconut in Jamaica. Oleagineux, 35: 551-554.

Rosas, J. L., Alatorre, R., Valdez, J. y Sanpedro, L. (1994). Crecimiento micelial y esporulacion de siete cepas de Hirsutella thompsonii y una cepa de Hirsutella nodulosa en leis medios lfquidos. Agrociencia. Serie Proteccin Vegetal. 5(1): 91-101.

Sabelis, M.W. (1996). Phytoseiidae. In: E.E. Lindquist, M.W. Sabelis and J. Bruin (eds.). World Crop Pests. Eriophyoid Mites. Their Biology, Natural Enemies and Control, Elsevier Sicences, Amsterdam, pp. 427-456.

Sampedro, L and Rosas, J.L, (1989). Selection de cepas de Hirsutella thompsonii fisher para Compatir al acaro del cocotero, Eriophyes guerreronis Keifer. I Bio ensayos de patogenicidal, Revista Mexicana de Micologia, 5: 225-232

Samson, R.A., McCoy, C.W and O'Donnell, K.L. (1980). Taxonomy of the acarine parasite. Hirsutella thompsonii. Mycologia 72: 359-377.

Santana D.L.Q. and Flechtmann, C.H.W. (1998). Mite (Arthropoda, Acari) associates of palms (Arecaceae) in Brazil. I. Present status and new records. Revista Brasileira de Zoologia 15(4): 959-963.

Sathiama, B. (1993). Seasonal abundance of the coconut white mite and its predators. In: M.K. Nair, H.H. Khan, P. Gopalasundaram \& E.VV. Bhaskara Rao (Eds.). Advances in Coconut Research and Development, International Science Publisher, N. York, pp.517-522.

Sathiamma, B., Radhakrishnan Nair, C.P and Koshy, P.K. (1998). Outbreak of a nut infesting eriophyid mite Eriophyes guerreronis (K.) in coconut plantations in India. Indian coconut J. 29 (2): 1-3.

Schicha, E. (1981). A new species of Amblyseius (Acari: Phytoseiidae) from Australia compared with tem closely related species from Asia, America \& Africa. Int. J. Acarol. 7: 203-216.

Schicha, E. and Gutierrez, J. (1985). Phytoseiidae of Papua New Guinea, with three new species, and new records of Tetranychidae (Acari). Int. J. Acarol. 11 (3): 173-181. 
Schliesske, J.(1988). On the gall mite fauna. (Acari : Eriophyoidea) of Cocos nucifera L. in Coasta Rica. Nachrichtenblatt des Duetschen Pflanzenschutzdienstees, 40: 124-127.

Seguni, Z. (2000). Incidence, distribution and economic importance of the coconut eriophyid mite, Aceria guerreronis Keifer in Tanzania. In Proceedings International Workshop on Coconut Mite, CRI. Sri Lanka, pp. 54-57

Siriwardena, P.H.A.P (1999). Development of a new technique to estimate the population of coconut mite Aceria guerreronis Keifer (Acari: Eriophyidae) in a single nut. Research report submitted for the partial fulfillment of the Degree of Bachelor of Science in Agriculture, University of Peradeniya, Sri Lanka.

Sosa Gomez, D.R. (1991). Production of three Hirstutella thompsonii varieties on semisolid media and differential effects of two fungicides. Anais da Sociedade Entomologica do Brasil 20: 155-163.

Sosa Gomez, D.R., Manzur, J. and Nasca, A.J. (1987). Influence of some pesticides on three varieties of Hirsutella thompsonii Fisher (Hyphomycetes: Moniliales). Anais de Sociedade Entomolologica do Brasil 16: 399-408.

Suarez Gonzalez y Almaguel, L. (1992). Metodologia de aplicacion del hongo Hirsutella thompsonii para el control del acaro del cocotero Eriophyes guerreronis. I Curso Internacional sobre produccion de Hirsutella para el control biologico de acaros. Guantanamo. Cuba. pp 53-59.

Suarez Gonzalez, A., Ordunez, E. y Almaguel, L. (1989). Efecto del saneamiento y del hongo biorregulador Hirsutella thompsonii sobre el acaro del cocotero Eriophyes guerreronis. Informe final de Etapa de Investigaciones. Lab. Prov. San.Vegetal. Guantanamo. pp .8-10.

Suarez, A.(1991). Distribucion y evalacion de danos del acaro Eriophyes guerreronis en plantaciones de cocotero de la region de Baracoa. Protecion de plantas, 1. pp.75-81.

Stejnberg, A., Doron-Shloush, S. and Gerson, U. (1997). The biology of the acaropathogenic fungus Hirstutella kirchneri. Biocontrol Sci. Technol. 7: 577-590.

Tanzini, M.R., Alves, S.B. Tamai, M.A., De Moraes, G.J. and Ferla, N.J. (2000). An epizootic of calacarus heveae (Acari: Eriophyidae) by Hirstutella thompsonii on rubber trees. Exp. Appl. Acarol. 24: 141-144.

Thistlewood, H.M.A., Clements, D.R. and Harmsen, R. (1996). Stigmaeidae. In: E.E. Lindquist, M.W.Sabel is \& J. Bruin (eds.). World Crop Pests. Eriophyoid Mites. Their Biology, Natural Enemies and Control, Elsevier Sicences, Amsterdam, p. 457-470.

Thomas, M.B., Blanford, S., Gbongboui, C. and Lomer, C.J. (1998). Experimental studies to evaluate spray applications of a mycoinsecticide against the rice grasshopper Hierogl"Phus daganensis, in northern Benin. Entomologia Experimentalis et Applicata. 87: 93-102.

Thomas, M.B., Langewald, J. and Wood, S.N. (1996). Evaluating the effects of a biopesticide on populations of the variegated grasshopper, Zonocerus variegatus. Journal of Applied Ecology. 33: 1509-1516.

Thomas, M.B., Wood, S.N. and Solorzano, V. (1999). Application of insect-pathogen models to biological control. In: Theoretical Approaches to Biological Control B.A. Hawins and H.V. Cornell (Eds.). University Press, Cambridge. pp. 368-384. 
Tseng, YH. (1985). A taxonomic study of the Tydeidae from Taiwan (Acarina: Trombidiformes). Part II. Journal Taiwan Museum, 38(2): 65-93.

Tuverson, R. W. y McCoy, C. W. (1982) Far-ultraviolet sensitivity and photoreactivation of Hirsutella thompsonii. Ann. Appl. Biol. 101: 13-18.

Umapathy, G., Ramaraju, K.; Karuppuchamy, P.; Srinivasan, M.R.; Balasubramani, V. Suresh, S.; Balasubramanian, G.; Mohan, S. and Rabindra, R.J. (2001). Survey on the incidence and intensity of damage caused by coconut mite, Aceria guerreronis Keifer in Tamil Nadu. Paper presented in National seminar on Emerging Trends in Pests and Diseases and their Management on 11-13 ${ }^{\text {th }}$ October, 2001 at Tamil Nadu Agricultural University, Coimbatore 3.

Van Driesche, R.G. and Bellows, T.S. (1996). Biological Control. Chapman \& Hall, New York, $539 \mathrm{pp}$.

Van Winkelhoff, A. J. and Mc Coy, C. W. (1984). Conidiation of Hirsutella thompsonii var. synnematosa in submerged culture, a facultative pathogen of several eriophyid and tetranychid mites. J. Invert. Pathol. 43: 59-68.

Varela A. M. (1993). Studies on the distribution and importance of the coconut mite Eriophyes guerreronis Keifer, as a pest of coconut palms in Tanzania, pp 13 (Unpublished).

Vey, A., Quiot, J.M., Mazet I. and McCoy, C.W. (1993). Toxicity and pathology of crude broth filtrate produced by hirsutella thompsonii var. thompsonii in shake culture. J. Invertebr. Pathol. 61: 131-137.

Yaninek, J.S., Mdgevand, B., Ojo, B., Cudjoe, A.R., Abole, E., Onzo, A. and Zannou, I. (1998). Establishment and spread of Typhlodrornalus manihoti (Acari: Phytoseiidae), and introduced phytoseiid predator of Mononychellus tanajoa (Acari: Tetranychidae) in Africa. Environmental Entomology 27(6): 1496-1505.

Yaninek, J.S., Megevand, B., Moraes, G.J. de, Bakker, F., Braun, A. and Herren, H.R. (1991). Establishment of the neotropical predator Amblyseius idaeus (Acari: Phytoseiidae) in Benin, West Africa. Biocontrol Science and Technology 1: pp.323-330.

Zuluaga C., I. And Sanchez P, A., (1971). La rona o escoriacion de los fructos del cocotero (Cocos nucifera L.) en Colombia. Acta Agronomica XX. (3): 133-339. 